\title{
パラレルシンポジウム（19）
}

\section{肝星細胞の病態生理と肝線維化, 肝血流調節}

6 月 25 日（金）第 5 会場（ホール D） 9:00～11:00

司 会: 円山 英昭 (高知医科大学 病理学)

渡辺 純夫（秋田大学 第一内科） 
肝星細胞の病態生理と朋線維化、

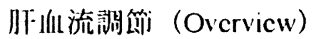

山山英昭 ${ }^{1)}$ 、渡辽純夫 ${ }^{2)}$

( ${ }^{1}$ 高知医科大学第一病理、 ${ }^{2)}$ 秋田大学第一内科)

朋星細胞（伊東細胞）は、故伊東俊头教授により、 その形態と機能面の特徵が初めて正確に報告（1951） されて以来、多数の研究が行われてきたが、細胞の分 晟・培養法の確立（1982）後は in vitro study が優勢之 なり、90年代初頭頃からの分子生物学的片究技法の導 入と合わせ、とくに肝線維化と類洞の血流調節におけ る朋星細匏の役割の重要性は分子や遺伝子レベルで実 㹬されつつある。

今回のパラレルシンボジウムの日的は、(1)〜(8)の口 演発表を通して、まず、星細肘の正常機能、次いで、 細胞の活性化と apoptosis について、病態面では特に肺 線維化について、その成立機序之俳御を中心に、星紬 胞の関与を最新の研究結果から明らかにすることにあ る :

(1). 静止期の肝星細胞の主要な機能であるビ夕ミンA 唄 蔵能について、不死化伊東細胞の 3 次元培養系を用い て、生体のレチノイド代謝における星紐胞の意義を考 察する。(2). 次に、類润の片洞節と関連して、星細胞 の収縮活動と、低分子量G蛋白質 Rho およびその標的 蛋白質 Rho-kinase との関速について。(3). 星絸胞活性化 の一指標である組胞增殖能の艺進機序を分雕直後と、

培差2 日目の星絸匏における DNA 合成能、G1 cyclin と PDGF 受容体の発現の有盐、およびPDGF 刺激後の シグナルカスケードの活性化から考察し、星細胞增殖 抑制物質の投与結果とあわせ報告する。(4). 筋楾維芽細 胞 (Mf) 化した星絸胞の分晠・培養後に生じる活性化 指摽（Mf 様形質枟換と $\alpha$-平滑筋アクチン発現量の增

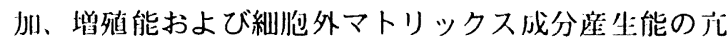

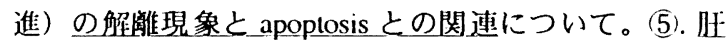
線維化の進展過程における plasminogen activator および plasminogen activator inhibitor-1 の㓰態と星細胞や TGF-B1 の関与について。( 6 ). 楾維化の改善過程におけ る matrix metalloprotcinases $と$ tissuc inhibitor of matrix

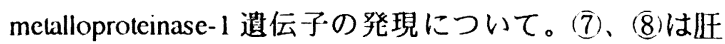
楾維化の制御及び治療の視点から、それぞれ、星細胞 の活性化動態の解析、TGF- $\beta 1$ 活性化阻害㓮による肝 楾維化抑制実験の絬果が報告される。

本学会では朋星縕胞について、これら8 演題の他に も優㧈た研笃（17顸題）がポスター展示により発表さ れており、そ扎ぞ㧈の問題点について、あわせ考察さ れることが望ま㧈る。
PaS-19-1

不死化伊東細胞の 3 次元培養系の確立と レチノイド代謝研究への応用

松浦知和 1、川田雅昭 2 、莲村哲 1 、筋野甫 1 、永森静志 1

(1東京热恵会医科大学内科 1、2睘境保健医学)

【目的】肝嵗類洞壁細胞の中で伊東細胞（星細胞）は、脂肪滴 にレチニールエステルを蓄え、血中のレチノールの維持と調節 に重要な細胞と考えられている。われわれは、伊東細胞にレチ ノイドがエステルとして特異的に蓄えられる機序として、伊東 綝胞の持つレチノールエステル化能特に lecithin: retinol acyltransferase (LRAT)に注目し研究を続けてきた。本研究の 目的は、肝臟伊東細胞が生体のレチノイド代謝の中で、どのよ うな役割をはたしているか明らかにすることである。このため、 1)レチノールエステル化能を指標として、不死化伊東細胞株を 樹立し、2)人工肝葴用充填型リアクターを用いて伊東緗胞を 3 次元培養し、レチノール代謝を検討した。

【方法】不死化肝葴伊東縕胞株樹立のために、温度感受性 SV 40 T Antigen 遭伝子導入マウス肝葴より類洞壁細胞を分離し、レ チノールエステル化能を指標として伊東細胞株をクローニンク した。高いレチノールエステル化能を持つ不死化伊東細胞を、 多孔性セルロースビーズを充填坦体とした充填型培養リアク夕 一で增殖培荃した。その後、增殖非許容温度で数日培窇し、SV 40 T Antigen の発現を抑制した後、培養液にレチノールを添加し た。経時的に培㺕液を採取し、レチノール濃度を高速波体ク口 マトグラフィーで計測した。

【成續】レチノールエステル化能を指標として樹立した伊東細 胞株では、平面培養下でレチノールを添加するとビタミン A 巣 光を発する脂肪滴を観祭することができた。この細胞を充填型 バイオリアクターで培㪨すると、セルロースビーズの腔内に長 い内皮下突起様の乫起を延ばし、さらに小さい spine でセル口 一ス上に固着しているのが走査型電子顕微鏡で観察された。経 代を繰り返し変異した株では、セルロース上での固着が困難で あった。充填型リアクターの潅流培溶液にレチノールを添加す ると、初期添加濃度が低濃度 $\left(5 \times 10^{-7} \mathrm{M}\right)$ の場合、レチノールの消 退は観察されなかった。しかし、高濃度 $\left(5 \times 10^{-6} \mathrm{M}\right)$ の添加ではレ チノールの消退を钼祭し、消退したレチノールは伊東細胞にエ ステル型レチノールとして蓄えられていた。

【考案】レチノールエステル化能を有する伊東緗胞が、類洞の 毒性レペルのレチノールを取り込み、血中のレチノール䝫度を 調節していると考えられる。

【結語】1)肝臓でのレチノイド代謝研究のため、レチノールエ ステル化能を指標にマウス肝臟由来不死化伊東細胞株を樹立し た。2)不死化伊東細胞を充填型バイオリアクターで 3 次元培善 し、レチノール代謝の実駼系を作成した。 
PaS-19-2

肝星和胞の収縮における低分子量 G 蛋白質 Rho 及びその標的蛋白質 Rho-kinase の意義

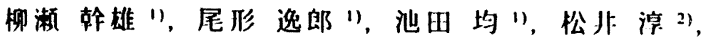
大野明彦 ", 富谷智明 ", 藤原 研司 2)

(1)東京大学消化器内科, 2)埼玉医科大学第三内科)

【目的】吓星細胞はその収縮を通じて類洞血流の調節 に関与すると考えられている。細胞外マトリックスと の細胞接着及び細胞荤動・収縮に重要な役割を果たす 細胞質内の低分子量 G 蛋白質Rhoは、GTPとの結合に より活性化し、標的蛋白質を介して作用を発現する。 標的蛋白質のひとつ Rho-kinase (ROCK-II, ROK- $\alpha$; 以 下 RK) は線維芽細胞等で、接着斑及ひストレスファイ バーの形成やアクトミオシン系の動態に直接関与する ことが知られる。我々はラット線維肝由来株化星細胞 より RKをクローニングし、その発現及び自己リン酸 化動態について報告した。今回、星細胞の収縮におけ る Rho及ひ RKの関与を明らかにすべく以下の検討を 行った。

【方法】SD系雄性ラットから単雄、継代した星細胞を 用いた。(1) I 型コラーゲンゲル上に星細胞を播栢。10\% FCS 含有 MEM で 72 洔间培羡後、無血清 MEM 培着下 で刺激因子 Lysophosphatidic acid (LPA; $10^{-7}-10^{-5} \mathrm{M}$ )を 添加後、ゲル周围を切り雕してゲル退縮を観察した。 また、Rhoの特罪的不活化因子 Botulinum C3 exoenzyme (C3; 0.2-2 $\mu \mathrm{g} / \mathrm{ml})$ の存在下に同様に検郡した。(2)上記培 美条件での $\alpha$-smooth muscle actin ( $\alpha$ SMA)発現をウェス タンブロット法にて娭討した。(3)フィブロネクチンを コートしたラテックスビーズを上記細胞上に播種後、 接着斑梏成物質F-actin、focal adhesion kinase、RhoA、 RK のビーズへの集簇を鉴光免疫染色にて検討した。 (4) RK の特暴的抑制剂であるピリジン誘導体 Y-27632 $\left(10^{-7}-10^{-4} \mathrm{M}\right)$ を、 $10 \% \mathrm{FCS}$ 含有 MEM 培養下の星細胞に 添加し、上記コラーゲンゲル退縮を観察した。

【結果】(1)LPA 浱度依存性にコラーゲンゲルは退縮し、 C3 投与にて退縮は抑例された。切り啡し 120 分後のケ ル面稹(直前を 100 として)：対照群, 95.6;10-6 M LPA, $81.7 ; 10^{-5}$ M LPA, $73.2 ; 10^{-5}$ M LPA $+2 \mu \mathrm{g} / \mathrm{ml} \mathrm{C} 3,98.5$ 。

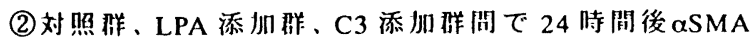
の発現に有意な差を認めなかった。(3)LPA 添加群では C3 添加群に比し、接着斑㩐成物質のビーズ周明への集 簇を高頻度に認めた。(4) Y-27632 添版により漕度依存 性にゲル退縮は抑制された。

【結論】Rhoおよびその標的蛋白質 RK は、朋星細胞 において接着斑形成に重要な役割を果たし、細胞外マ トリックスとの接着を規定することで、細胞収綰に関 与することが推定された。
PaS-19-3 ラット培養星細胞の増殖における PDGFシグナルカスケードの役割とその制御機構 河田則文，関 守一，黒木哲夫

(大阪市立大学第三内科)

[目的]培養星細胞の增殖はPDGFによって強誘導さ れることが知られているが, PDGFが星細胞上の受容 体(PDGFR)に結合して，核分裂を誘導するまでのシ グナル伝達機構に関しては未だ不明な点か多い。今回 は, 星細胞におけるPDGFRの発現動態, PDGF刺激後 のチロシンリン酸化蛋白, MAPキナーゼ活性化, イ ノシトールリン酸代謝, protein kinase B/Aktの活性化 などを調べた。さらに，各種特異的阻害剂を用いるこ とにより, PDGF依存性星細胞增殖に最も重要である シグナルの同定をおこなった.

[方法]星細胞はWistarラットから分離し, 10\% F BS 含有DMEM中で培養した。DNA合成を $\left[{ }^{3} \mathrm{H}\right]$ thymidine やBrdUの取り込みで, PDGFRßやcell cycle proteinの 発現をWesternやNorthern blotで検討した。PDGF刺 激後のチロシンリン酸化蛋白, MAPキナーゼ活性化, イノシトールリン酸代謝, protein kinase B/Aktの活性 化をリン酸化特異的抗体やキットを用いて検討した。 星細胞增殖抑制物質 $\mathrm{dBcAMP}$, チロシンリン酸化阻害 剂resveratrol，MAPK阻害剂PD98059, p38MAPK阻 害剂SB203580，さらにPI3-kinase阻害剂LY294002の 効果についてそれそれ検討した。

[結果]分離直後の星練胞ではDNA合成がみられず， 紐胞は G0/G1期に存在し, G1 cyclin (cyclin D1, cyclin D2, cyclin E) は発現していなかった。さらに， PDGFR $\beta$ の発現もみられなかった.PDGFRßは培養 2 日後になって突然誘導され，この時期に一致して G1 サイクリンが発現し S 期細胞が出現した. dBcAMP (1 $\mathrm{mM})$ は星細胞增殖を完全に抑制したが，これはCREB のSer133リン酸化と同時にPDGFR $\beta$ P 1 1 cyclin 発現抑 制を伴うことが明らかとなった。PDGF刺激により $180 \mathrm{kDa}$ のPDGFRがリン酸化する.Resveratrolは PDGFR $\beta$ 量に影響せずに，180 kDa蛋白のリン酸化を 濃度依存性に抑制し,さらに, cyclin D1発現とDNA 合成を抑制した。PDGF刺激により，MAPキナーゼが 活性化したが，PD98059PSB203580の增殖抑制效果 は軽微であった。一方，PDGF刺激でイノシトールリ ン酸代謝の充進とprotein kinase B/Aktのリン酸化が誘 導された。LY294002はPDGFRßの発現を抑制するこ となく, protein kinase B/Akt活性化, cyclin D1発現 とDNA合成を濃度依存的に抑制した。

[結論]以上の結果から，PDGFに依存した星細胞增 殖は, PDGFR $\beta$ 発現 $\rightarrow 180 \mathrm{kDa}$ 蛋白リン酸化 $\rightarrow$ PI3 kinase活性化 $\rightarrow$ protein kinase B/Akt活性化 $\rightarrow \mathrm{G} 1$ cyclin 発現 $\rightarrow \mathrm{S}$ 期移行という力スケードが主要経路である可 能性が示唆された。 
PaS-19-4 培羡奸星絊咆における活性化指標の解维現 象と apoptosis

真下由美，持田智，稻生実枝，石川必子，名越澄子，

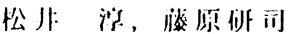

(埼玉医科大学第三灯科)

【日的】正常川より些雖した星細胞をプラスチック IIII

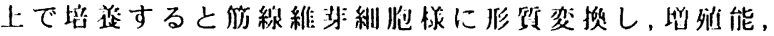
細胞外分泌蛋白の合成能および平滑伤 $\alpha$ アクチン発現 が增強する。従来，これら 3 種の現象は星絒胞の活性 化指標と見なされ，一致して変動するものと考えられ

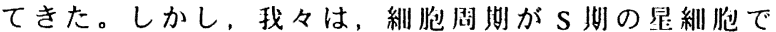
は一侍的に平滑節 $\alpha$ アクチンの発現が減弱し，雨者が 解跳することを見出した(第1回日本㠼战学会大会)。

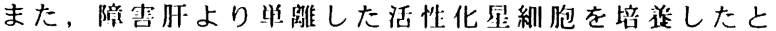
ころ，3指標は全く解彫して変動したが（第85 回日本 消化器病学会総会), 今回, この現象には星細胞の apoptosisが閔与する可能性を観察したので報告する。

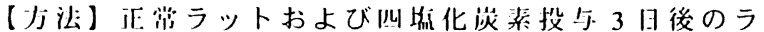
ットから, collagenase 川洲流 metrizamide 比重邀心汒

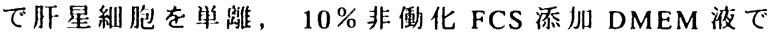
培陡した。培着 3 および 10 日後に, ${ }^{3} \mathrm{H}$-チミジンの DNA 取込により增殖能を, Northern blottingにより平滑 $\alpha$ ア クチンとVEGFの発現を評洒した。星紃胞の apoptosis は TUNEL 染色及び扗出した DNAにおける laddering の存曼で評仙した。

【成縜と考案】(1) 正常ラットより単䂪した星細胞にお けるDNA 合成は，培趸3日後では柽微であったが，

10 日後には 100 倍以上になった。平滑笳 $\alpha$ アクチンと 絒胞外分泌蛋白の一つであるVEGFの発現は，何れも 培恙 3 日後に比して 10 日後の星細胞で兮進していた。 (2)四盐化茨素障害ラットより単跳した星紐胞では, DNA 合成が培意 3 日後でも活発であったが，10日後 には低下する傾向が認められた。一方，平滑筋 $\alpha$ アク チンの発現は坮猛3日後に比して10日後で增骀したが VEGF発現は逝に減枃した。

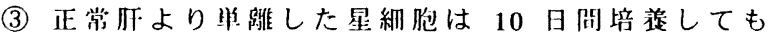
apoptosisは認められなかったが，四䍀化荻菜陪䨔朋出

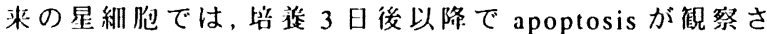
れた。

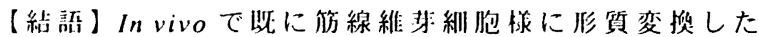
星縕胞を培旗すると、活性化を反吙するとされてきた 指標が解颜して変軼した。特に，增殖能や縕胞外分泌 蛋白の合成能は，培金により低下したが，apoptosisに 陷ることがその要因になりうると推定された。培竨星

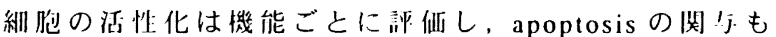
念预に雷くことが重荘と考えられた。
PaS-19-5

ラットク下線維化過程における plasminogen

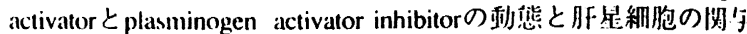

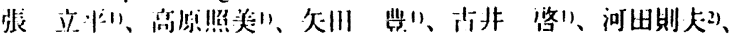
渡说则治门

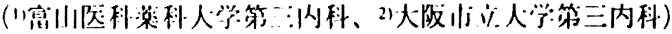

【H的】 matrix metalloproteinase (MMP) は川下線維化の進展過程て 重妆な役剕を果たすが、その活悱化にはプラスミン等のセリン プロテアーゼが阅与している。プラスミンは、プラスミノーゲ ンから、urokinase type plasminogen activator (uPA), tissue type plasıninogen activator (IPA)の作湖によって作られるが、朋線維化

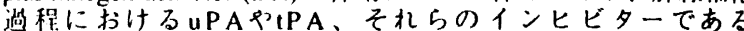
plasminogen activator inhibitor -1 (PAI-1)の癷現動態は末だ师らか

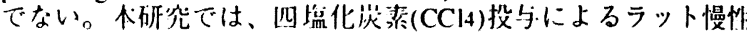

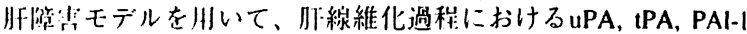

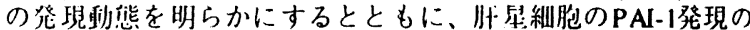
阅字についても恰討した。

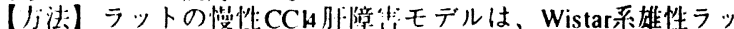

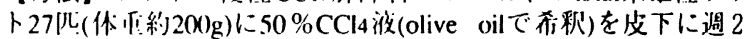

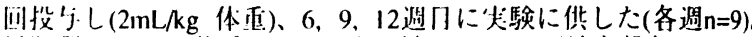

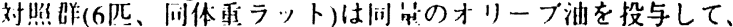

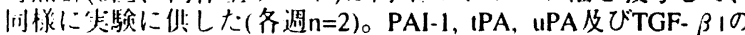

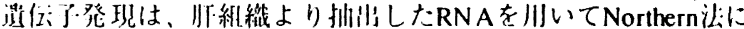

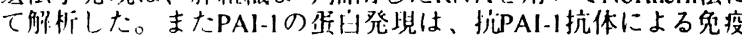

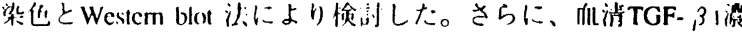
度をELISA泣にて测定した。

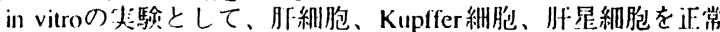

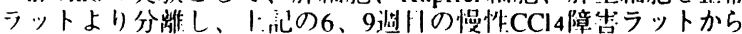

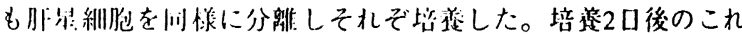
ら各細胞を州いて、PAI-1のmRNAと修门の発現をそれぞ机

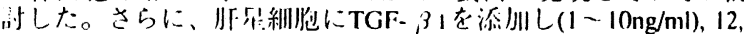

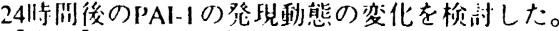

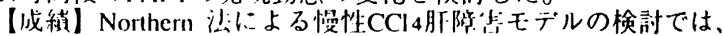

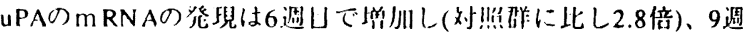

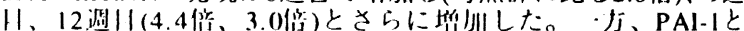

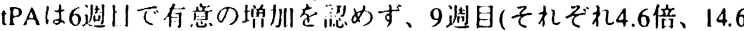

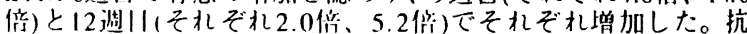

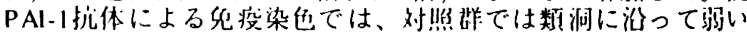

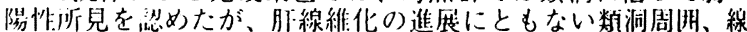

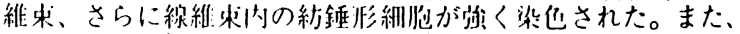
Westem blot 泣による椧部では、線維化にともないPAI-1の発現

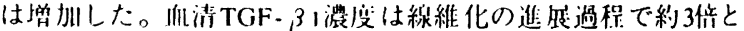
增加した。

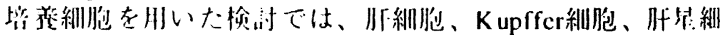

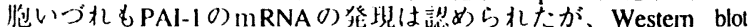

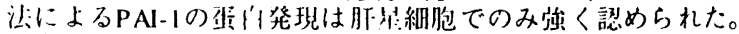

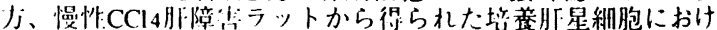

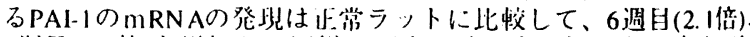

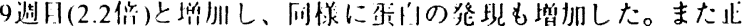

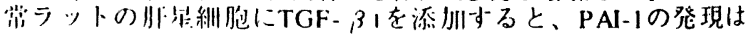

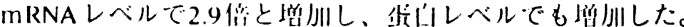

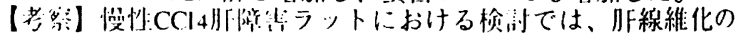

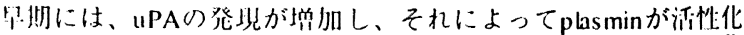

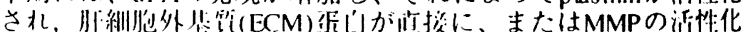

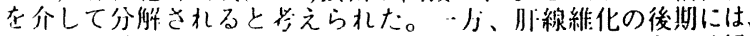

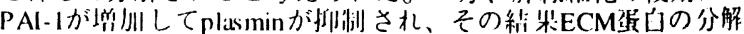

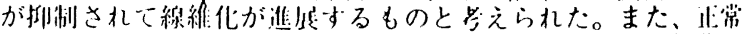

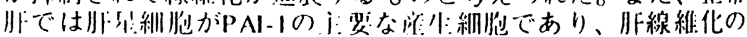

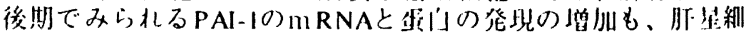

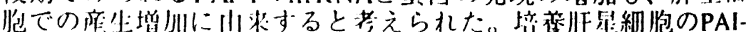
1 癹現はTGF-ß1で促進され、ラットの悛性CCl4朋障害でみら

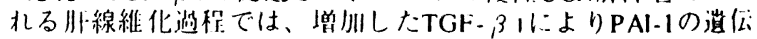
了発現が促進さ机ると考えられた。

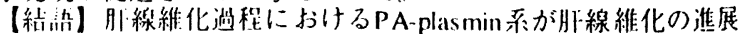

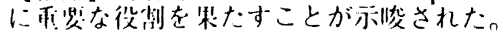


PaS-19-6 奏験的ラット肝線維化改善過程に おけるMMPsとTIMPsの遗伝子発現

岡崎 堤”，渡辺 哲"，朴沢重成"，九山勝也”

("東海大学医学部地域保健学, ${ }^{21}$ 国療久里浜病院)

【目的】我々は, 実験的ラット肝線維化過程における コラゲナーゼの関与についてこれまで報告してきた が, 四塩化炭素投与中止後肝線維化が改善することよ り，改伹過程にもコラゲナーゼが関与することが示唆 される.これまでのところ間質性コラゲナーゼに関し ては改善過程で增加するとの報告はみられない。そこ で，今回我々は実験的ラット肝線維化改善過程におけ る metalloproteinases (MMPs)の動態，特に間質性コラゲ ナーゼについて検討した。

【方法】体重 $150 \mathrm{~g}$ のWistar系雄性ラットに30\%四塩化炭 素溶液（オリーブ油）を $1 \mathrm{ml} / \mathrm{kg}$ の割で週2回腹腔内に投 与し，肝線維症を作成した。8週間投与後，2日目，5日 目，7日目に肝組織を採取した。対照群はオリーブ油の みを投与した。肝組織より直ちにtotal RNAを抽出し, random primerにてcDNAを合成した後それぞれのprimer を用いてMMPsの遺伝子発現をPCRにて検討した。検 討したのは，間質性コラゲナーぜ, MMP-2, TIMP-1で ある.G3PDHの遗伝子を別のチューブで同時に增幅 し，内部コントロールとした。

【成績】四塩化炭素8週間投与により，全てのラットに 吓線維症が作成されたが, 再生結節はみられなかっ た. 四塩化炭素投与中止後7日目には肝線維症が著明に 改善していた，RT-PCRによる検討では，間質性コラ ゲナーゼは，四塩化炭素投与4週目に弱いシグナルがみ られ，8週投与2日目にはシグナルが検出できないが, 中止後5日目には增加した. TIMP-1 も同様に投与中止 後5日目に增加がみられ，7日目には減少した。MMP-2 は，四塭化炭素投与中止後5日目，7日目とシグナルが 增強してきた。

【考案】肝線維症におけるMMPsの関与については, 主にTIMPの変動が報告され，間質性コラゲナーゼはわ ずかに検出されるものの, 線維化過程及び改善過程で は変化しないとされている. 我々のRT-PCRによる検 討では，線維化過程の初期，4週目にわずかに発現がみ られ，改普過程5日目には発現の増強が観察された。し かし, TIMPの発現增加もみられることより，実際にコ ラゲナーゼ活性がどのように変化しているかを今後検 討する必要がある。正常肝では間質性コラゲナーゼの 遺伝子発現がみられず, 改善過程で增强することは， 回復胡に間質性コラゲナーゼ転写话性を高める因子 が存在することを示焌しており，今後この因子の所师 が奸線維症の治療につながるものと划街される.

【結話】実験的ラット朋線維化モデルにおいて，線維 化改羛過程で間質性コラゲナーゼたけけではなくTIMP-1 の遗伝子発現が認められた。
PaS-19-7 mitogenic activityおよびfibrogenic activity から見た培䏠ラット肝星絒胞の活性化動態の解忻 鈴木千衣子、啙野倠三、坂井田功、坂口栄樹、濑川 誠、弘中孝治、内田耕一、沖田極 山口大学医学部第一内科

【目的】师硬変への進展における責任縕胞である奸 星細胞(HSC: hepatic stellate cell)の活性化動態を解明す ることは玣線維化に対する治療戦略を考える上で極め て重要である。そこで培庭ラットHSCの活性化過程を 細胞增殖能(mitogenic activity)およびコラーゲン産生能 (fibrogenic activity)の雨侧面から解明することを目的と した。【方法】450g Wistar系雄性ラットを用い既報 のごとくHSCを分戨後培痿14日間(day0 - day14)の以下 の項目を解析した(Primary Culturc群)。(1)細胞数:シャ ーレ上のHSCをtrypsin-EDTAにてはく離し全細胞数を 計测した。(2)mitogenic activity: 細胞数测定後propidium iodideにてDNA染色を行いFlow Cytometryを用いて細胞 周期を解析し細胞增殖の評仰として分裂期(G2/M)の細 胞数を算出した。(3)fibrogenic activity: procollagen type I, type IIIおよびTGF- $\beta 1$, TGF- $\beta$ receptor typc IIの発現を Northern blot法により解析した。さらにPrimary Culture 群において培产7日目に再度HSCをtrypsin-EDTAによ りはく靠後継代培峜したものについて7日間にわたり mitogenic activityを求めた(Sccondary Culturc群)。【成 結】(1)mitogenic activity:day0からday1においてはHSC のほとんどがG0/G1 phascであったがday2においてS phaseのHSCが藷明に增加しDNA合成閒始が磼認され た。さらにday3において G2/M phaseのHSCが有意 $(\mathrm{P}<0.05)$ に增加し(day2 vs day3: $0.25 \pm 0.38$ vs $18.46 \pm$ 9.30\%)HSCの分裂・增殖が閏始した。day4以降G0/G1 phaseのHSCが濑減し強い分裂・增殖能が持続したが、 day6以降day14までは分裂能は低下した。Sccondary Culturc侨では継代直後にわずかながら G2/M phascの HSCが認められたものの速やかに低下した。(2)細胞 数:day4までは $2.2 \times 10^{5}$ cellsで細胞数の増加はなかった がday $5\left(2.9 \times 10^{5}\right)$, day $6\left(3.2 \times 10^{5}\right)$ とHSCの細胞数が增 加した。(3)fibrogcnic activity:day3以降全てのmRNAの 発現が確認された。特にprocollagen type I mRNAは HSCの增殖活性に伴い增加した後HSCの増殖活性が低 下しても高い発現levelを維持した。【考案】HSCは 培裉初期に一峰性の急激な分裂增殖活性を示した。一 方コラーゲン限生は增殖活性に伴い漱增した後も長期 にわたり高い産生能を維持した。すなわち種々の程度 に活性化されたHSCが混仕する慢性肝炎という病態に おいて肝硬変への進展を阻止するためにはHSCの增殖 制御、コラーゲン産生抑制あるいはコラーゲン溶归促 進などがHSCの生理活性に合致した治療戦略と考えら れた。【絬鿉】HSCの活性化典態をmitogenic activity およびfibrogcnic activityの同侧面から呵らかにするこ

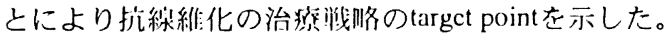


PaS-19-8 TGF- $\beta$ 活性化阳㫪剂による川F緗維化治㾱

楽の閒発

奥野正隆、秋由國治、森枷久隆

(岐㚖大学第一内科)

【日的】旰線維化には、显縕胞より分泌される transforming growth fact or (TGF)- $\beta$ が深く関与 している。TGF- $\beta$ は、星絒胞の活性化を促し、細胞 外マトリックス座生を刺激する強力なfibrogenic cytokineである。我々は、星細胞におけるTGF- $\beta$ 活 性化機序の解朋 (He patology 1997；26:913, FEBS Let $1997 ; 411: 102$, BBRC 1996;221:565) から、 潜在型TGF- $\beta$ の proteolytic activation の例御が、 現在治療法のない肝線維化の治療上重要な戦略目標に なると考え、臨床応用が可能なprotease inhibitor の閒発を行ってきた。

【方法】1) ラット星細胞培養系を用い, plasmin, basic FGFあるいはレチノイン酸刺激により誘導され るTGF- $\beta$ 活性化の抑非を指摽に、20種類の化合物を screeningした。2) ブタ仙清を $0.5 \mathrm{ml} /$ 週 2 回、16 週間腹腔内投与して作製した㠼線維症ラットに、1） で得られた化合物のうち安全性が確認されたFOY305 を0、1000、2000 p pm 混伹投与して、TGF- $\beta$ 発現 (northern blot、先疫染色、bioassayによる盐白定 量)、星細胞の活性化 $(\alpha-$-smooth muscle actin 陽 性化)、肝線維化（縕織hydroxyproline 量、Azan 染

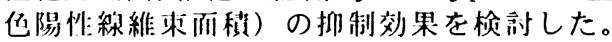

【成細】1)上記のいず㧈の籼激によっても、足組胞 からのTGF- $\beta$ の培地への放出・活性化がられた。 化合物のうち 4 つが、いずれの刺激によるTGF- $\beta$ の 活性化をも著朋に $(p<0.01)$ 抑例した。このうち、怒 全性が確認され経口投与が可能な化合物は2つ

(FOY305, FOY3403)であり、ともに広域スペクト ルのprotease inhibitorであった ( $\mathrm{J}$ Hcpatol, in press)。2) ブタI IfI清投与により、朋㙏死を伴わない 朋線維化が形成され、星縕胞の活性化とTGF- $\beta$ $\mathrm{mRNA} /$ proteinの発現の有意な元進が観察された。 FOY305投与により、投与量依存性に有意な（いずれ $も \mathrm{p}<0.05)$ 星絸胞活性化の抑制、TGF- $\beta$ 発現の低下、 圷線維化の抑制が観察された。なお、FOY305投与に よる体重抑例などの副作用はみられなかった。

【考案】我々は、 plasmin依存性あるいは非依存性の TGF- $\beta$ 活吽化について练告してきた。今回のin vitro, in vivoの系はいず扎もplasmin依存性であり、 protease inhibit orはplasmin 活性の抑例を介して TGF- $\beta$ の活性化を抑例したものと排定された。これ により显絒胞の活非化、ひいては亥維化の抑制が得 られたものと考えられた。

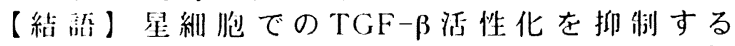
protcase inhibitorを間発し、その投与によりブタ

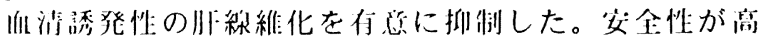
く、経口投尔が可储なことから、新しい朋楾維化治汸 楽となりうる闭能悱が示唆された。 